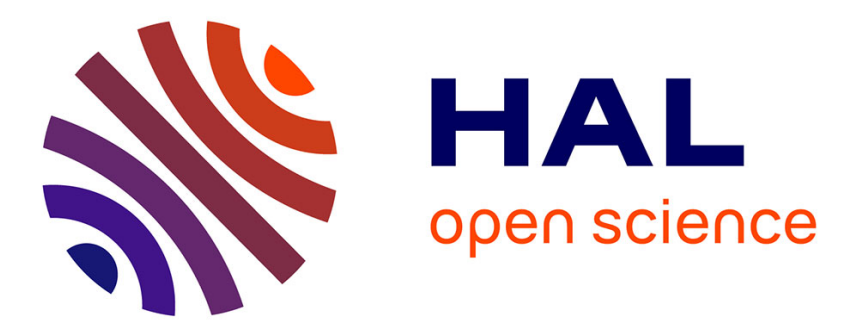

\title{
For a Didactical Approach to Electroacoustic Musics: The example of Metallics by Yan Maresz. Pascal Terrien
}

\section{To cite this version:}

Pascal Terrien. For a Didactical Approach to Electroacoustic Musics: The example of Metallics by Yan Maresz.. Organised Sound, 2013, Best Practices in the Pedagogy of Electroacoustic Music and its Technology, 18 (Special issue 2), pp.161-169. 10.1017/S1355771813000071 . hal-01879222

\section{HAL Id: hal-01879222 \\ https://hal-amu.archives-ouvertes.fr/hal-01879222}

Submitted on 17 Nov 2018

HAL is a multi-disciplinary open access archive for the deposit and dissemination of scientific research documents, whether they are published or not. The documents may come from teaching and research institutions in France or abroad, or from public or private research centers.
L'archive ouverte pluridisciplinaire HAL, est destinée au dépôt et à la diffusion de documents scientifiques de niveau recherche, publiés ou non, émanant des établissements d'enseignement et de recherche français ou étrangers, des laboratoires publics ou privés.

\section{(c)(1)}

Distributed under a Creative Commons Attribution| 4.0 International License 


\title{
For a Didactical Approach to Electroacoustic Musics: The Example of Metallics by Yan Maresz
}

\author{
Pascal Terrien \\ LUNAM, Université catholique de l'Ouest, Angers \\ Observatoire musical français (EA 206), Paris Sorbonne
}

\begin{abstract}
:
Our paper observes the conditions of reception and understanding of music using the theoretical concepts of learning (Chevallard, 1985, Brousseau, 1998) adapted to the teaching of these various musics (Terrien, 2006). We verify, in the light of an epistemological questioning, the nature of electroacoustic music, and if the didactic transposition (Verret, 1975 Chevallard 1985) applied to the work of Yan Maresz, Metallics, allows us to understand the phenomena of music (Listening, Intentionreception: issues of perception and interpretation), and identify issues of language. Our contribution is a tool for reflection on a teaching approach that relies on new teaching methods in the teaching of this music.
\end{abstract}

\begin{abstract}
In the first place you must realize that it is rarely up to you to propose what he [Émile] ought to learn. It is for him to desire it, to seek it, and to find it - to you to put it within reach, to skillfully give birth to this desire, and to furnish him with the means of satisfying it. From this it follows that your questions should be infrequent but well chosen. Since he will always have more questions to put to you than you to him, you will always be less exposed and more often able to ask him, "Why is it useful to know that which you are asking me?"

(Jean-Jacques Rousseau, Emile, or On Education, Book 3, 618. Translation:http://www.ilt.columbia.edu/pedagogies/rousseau/Contents2.html)
\end{abstract}

\section{Introduction}

Today, no thought should be given to the arts without an analysis of the technical phenomenon: this argument cannot be ignored. With the development of electronic arts ${ }^{1}$, this issue is brought up explicitly, not only for undeniable reasons concerning the origin and history of these modes of expression and the intrinsic nature of the media used, but also because of the progressive and systematic convergence and merging of the theoretical and "ideological" issues belonging to both worlds, a convergence that also concerns their factual energies and operating procedures. (Barbanti, 2004, 21)

When an electroacoustic piece is taught, its status shifts from that of a work of art to that of a learning object. This metamorphosis compels the teacher to use the inevitable epistemological questioning to become acquainted with the nature and function of the various - not only musical — elements constituting the piece (Bachelard, 1936; Kuhn, 1969). Didactics is a

\footnotetext{
${ }^{1}$ A term coined by Frank Popper in his book: Art of the Electronic Age, Thames and Hudson, 1993. French translation: L'art à l'âge électronique, Paris, Hazan, 1993.
} 
discipline enabling the deconstruction of a piece into as many elements as it is made of (musical, technical, scientific, aesthetic, etc), and allowing its teaching and study. Didactics is class preparation time while pedagogy is class time per se. Though music is an art, its teaching belongs to the field of science and techniques (episteme and tekhne), and more particularly to the field of hermeneutic sciences (Develay, 1997, 17-31) ${ }^{2}$. Today, it is inconceivable that any act of teaching could not have been prepared didactically by addressing the epistemological issues attached to the objectives and aims pursued. In the case of electroacoustic music, listeners have only their ears to give meaning to what they have just heard, and meaning always draws on what listeners feel during the aural perception of music (Terrien, 2006). As for teachers, they have the same abilities and generally have deeper knowledge of musical phenomena thanks to their sensory ${ }^{3}$, technical and scientific education. Their task, however, is to help students/pupils/listeners recognize certain aural phenomena and the means used to produce them. To help them understand and make an electroacoustic piece their own is a particular exercise because the sound world in which listeners are immersed is new, and cognitive references may be lacking. Sounds never heard before are disconcerting! These new sounds are the result of differing modes of production from those usually used by a composer. "Manufactured" with new tools, these musical pieces also derive from a partnership between a musician and specialists in electronic and computer technologies. The epistemological nature of the piece is radically altered, whereas its function is hardly, if ever modified compared with other musical pieces belonging to the history of music.

This question of the nature of an electroacoustic piece is one of the major issues didactic teachers should deal with. Epistemological questioning will help them better understand its purpose; make the right choices when considering the musical phenomena they want to study with their students; decide on the time they allow listeners to hear the music. As Yves Chevallard wrote about the anthropological theory of didactics: “... What we assign value to, what we share, is the musical piece apprehended in its structure rather than its functions, which then disappear in the apparently endless scattering of its 'applications'." (Chevallard, 1999, 228).

Our assumption is based on the help didactic questioning can bring to teacher-musicians and teacher-composers specialised in electroacoustic music. We think that the tools used in didactics contribute to a better understanding of the components, elements and features characteristic of this musical trend, and thus help find the best strategies to teach them.

In this article, our aim is to show the relevance of this assumption by first recalling some of the major concepts of the didactic theory. Then we will offer a didactic analysis of Metallics, a musical piece by Yan Maresz, using some of these didactic tools. We will conclude with an analysis and discussion of the teleological contribution to this new relationship between didactics and music in the sector of musical education, and more particularly of electroacoustic music.

\section{Regarding didactics}

\footnotetext{
${ }^{2}$ Michel Develay's paper allows making this claim even if we believe that formal and empirical/formal sciences are as necessary as the study of music.

${ }^{3}$ By "sensory", we mean what makes their musical nature and expression.
} 


\section{1. The epistemological questioning}

We consider the classroom as a space for interaction that needs to be controlled: interactions between teacher and student; interactions between the musical piece and the listener; interactions among students. These interactions are specific to education, which is the supervision of students by a teacher with a view to new knowledge acquisition. In any educational relation, an imbalance exists in the relationships between teachers and students as congenial as they may be - which cannot be concealed or erased. Even in a socioconstructivist ${ }^{4}$ approach, in which students co-construct knowledge under the mediation of a teacher, the organisation of the course is the responsibility of the latter.

But before reaching the educational phase - that of an exchange with students - the teacher's task is to become acquainted with the nature and functions of the object he/she has decided to teach. The teacher chooses what knowledge their students are supposed to acquire, and organises the various stages of acquisition of this knowledge. This pre-teaching activity falls within the province of didactics that is the study of an object that is not clearly specified in the initial stage, but which is presented in its wholeness, in its "structure" to refer to Chevallard's words (1999). In other words, an electroacoustic piece is a work of art. To choose it for study is to make it a learning object. We call didactic transposition the research and analysis carried out by the teacher allowing the work of art to become a learning object. Such a deconstruction process (Brousseau, 1998) describes, identifies and explains those elements contributing to provide a shape to an intuition and artistic experience. By deconstructing the piece, by taking it out of context - from the concert hall to the classroom - the teacher turns it into a fragmented, broken up learning object. This fragmentation gives the teacher the opportunity to organize its teaching. Didactics is not a method, it is a discipline that makes it possible to study the processes involved in the transmission and learning of a work of art converted into a learning object for the sake of teaching (Vergnaud, 1978).

The pre-teaching activity is organised into three stages that are all based on the learning objectin this instance, the musical piece called Metallics by Yan Maresz. On the one end, it aims at the best possible knowledge of the object, but on the other end it only retains a number of fragments in order to elaborate one, or even several, teaching scenarios that will help students learn. Such switching back and forth between the "scholarly" ${ }^{5}$ and the "taught" item is called didactic transposition (Appendix 1). The first part of this research involves an epistemological questioning on the nature of the object, meaning sciences or scientific knowledge allowing a better understanding of pedagogical material. A musical work is art born from human endeavour that, as such, uses and organises different elements in order to arouse our senses, feelings and intellectual power. Consequently, this work of art also provokes our personal analysis. The epistemological questioning of the work of art enables teachers to differentiate its

\footnotetext{
${ }^{4}$ Educational method, stemming from psychology, claims that learners are responsible for what they and the group are learning through the reciprocal sharing of knowledge. These theories draw on Lev Vygotski's works (18961934).

${ }^{5}$ If the point here is not to express a mathematical formula, we consider the musical piece - a finished object - as scholarly knowledge.
} 
founding elements, put them in order of priority and organize them, and above all to better understand the work, grasp its structure and shape it into a form of reality different from what they imagined. For example, in the case of Metallics by Maresz, the teacher will do research into the various mutes using his knowledge of organology and also of acoustics to explain the different effects. Teaching electroacoustic music requires such an analysis. We share Pascale Criton's idea that this type of music incorporates a large amount of technology.

Music is fundamentally related to tékhnè. Its materiality is an integral part of a large set of tools and techniques that range from the creation of sounds to "composition" in the broad sense of the word, to the interpretation. [...] Music's technical scope is the result of a combined wealth of techniques issuing from multiple fields: geometry, mathematics, physics, mechanics, materials and their resistance, etc. (Criton, 2004, 245)

Like other authors (Battier, 2003; Delalande, 2003, et al), we believe that electroacoustic music has changed the relation between listeners and music in general. The point is then to study the musical piece in terms of its potential aural perception, cognitive psychology applied to listening (Mc Adams, Bigand, 1994) and its socio-emotional dimensions, and to use - or adapt - analytical methods to these new types of production (Roy, 2003). The relevance of epistemological questioning prompts teachers to focus on the history of electroacoustic music and hence to provide some background to the studied piece and put it into perspective within the whole sum of electroacoustic music. This way of studying the electroacoustic piece transfers it into the scope of epistemological analysis where the scientific dimension - which is no longer only hermeneutic — describes it as a very complex object calling upon other disciplines outside the humanities.

This epistemological questioning gives a different perspective to the musical piece, and enables teachers to distance themselves from it, analyse and examine it with alternative viewpoints. This first step named “didactic transposition" casts new light on the piece, allows a new appraisal inducing teacher to make choices among their teaching goals.

\section{2. Didactic transposition}

There are two types of didactic transposition (Verret, 1975): external and internal ${ }^{6}$. Develay, like Chevallard, argues that the purpose of didactic transposition is to place knowledge within a social and historical context (Develay, 1991). To simplify, external transposition is related to institutional constraints (the curriculum), while internal transposition refers to personal constraints (classroom realities). In a school context, external didactic transposition depends on the requirements of the educational institution, on those who elaborate educational programmes and define objectives - what Chevallard calls the noosphère (Chevallard, 1985) - while internal didactic transposition examines the way referential knowledge is analysed by teachers through textbooks or teachers’ physical gestures in the classroom.

\footnotetext{
${ }^{6}$ There are two forms of didactic transpositions: the external didactic transposition - that of experts creating a curriculum -, and the internal didactic transposition - that of a teacher preparing for his class.
} 
Regarding the teaching of electroacoustic music, external didactic transposition is supposed to be operated by the musical institutions in charge of teaching, or research centres developing educational programmes. The objectives are defined by a committee of experts who, depending on the policies adopted by schools or research centres, decide on the objectives to be fulfilled in order to create the material necessary for knowledge acquisition. Internal didactic transposition is the transposition of those methodologies implemented to fulfil the objectives set out in the programmes: methods, software, research papers accessible to the general public, etc.

We are aware that this transformation of scholarly knowledge into knowledge to be taught has to meet aesthetic, philosophical, scientific, as well as political and social expectations. In our society, external didactic transposition significantly influences curriculum content. At a lower level, internal didactic transposition reveals teachers' ideological approach to knowledge. The act of didactic transposition is the demonstration of political and ideological choices that teachers cannot ignore (Appendix 2). Whether we deal with concrete music, electroacoustic music, or mixed music, approaches are not necessarily the same, and expectations in terms of creation do not always use the same tools and procedures.

Through the tools it uses, didactic transposition clearly indicates the choices made by institutions or teachers. Some software tools aimed at school children or specialists specify the objectives set out by institutions (See IRCAM ${ }^{7}$ : Music Lab 1 and 2, Open Music,Max/MSP; GRM $^{8}$ Tools, Acousmographe 3; ACROE: Genesis, Mimesis (modulator); etc).

When studying a musical piece, the didactic transposition operated by teachers does not escape such injunctions. There are two main reasons for this: the first one is linked to teachers' professional and university education, personal tastes, and an intellectual focus on rather scientific subjects; the second one is linked to the nature of the studied piece and the material used by teachers to broaden their knowledge - this material generally being directly associated with the theoretical framework that prevailed at the time of composition (the composer's technical, musical and aesthetic choices). Both aspects of didactic transposition are not necessarily explicit but they do exist, and if language does not seem to reveal them, processes do.

Another aspect of didactic transposition concerns the purpose of the teacher's didactic work. For whom is this work intended? What objectives are teachers striving for with pupils and students? What tools are available to teachers? How can teachers help students develop new knowledge and acquire new skills? What strategies can be implemented so that students acquire these skills?

All these questions clearly come to light at the stage of internal didactic transposition. The answers are not insignificant and the choices made by teachers also depend on their target audiences. Not asking questions means ignoring the learner, not considering him/her as a player

\footnotetext{
${ }^{7}$ IRCAM: Institut de Recherche et de Coordination Acoustique/Music, Paris.

${ }^{8}$ GRM: Groupe de Recherche Musicale, Paris.
} 
in the educational experience, and probably not letting him/her have access to what he/she is here for: to learn to give meaning to the music he/she is listening to, understand it, hear it. Whether it concerns specialised or general education, that is where the challenge lies and didactic transposition is one of the numerous tools available to teachers.

\section{3. The didactic contract}

The last aspect I wish to consider regarding didactic engineering is the nature of the didactic contract (Brousseau, 1978-1986). This contract is not necessarily explicit in the context of a lecture. Indeed, during a lecture, learners are not fully in charge of their own learning experience contrary to a learning sequence when they participate, develop a project or build new knowledge collaboratively. The didactic contract proposes dividing up responsibilities between learners and teacher. However, its implementation totally depends on its initiator, namely the teacher. I will not further develop this concept of didactic contract, but it is implicit and always operates in an educational relation. Teachers must be able to identify and include it in their educational strategies.

\section{The musical piece; Metallics by Yan Maresz}

The epistemological questioning upon Metallics by Yan Maresz is twofold. The first point concerns the nature of the work, the second one its function. By nature I mean what constitutes the work on the musical, scientific, formal as well as aesthetic levels; and by function I mean what it is intended for.

\section{1. The nature of Metallics: a few facts...}

The piece was written for solo trumpet and live electronics in 1994 and partly played for the first time in 1995. It belongs to the so-called mixed techniques musical pieces, which involve one or several instrumentalists combined with electronic devices and computers interacting in real time. This piece explores the anthropological dimension of electroacoustic music. Maresz says that Metallics is: " a musical piece exploring the phenomena linked to the perception and legibility of formal organisation, structuring the musical material into a language that I [the composer] would like to be as straightforward and communicative as possible” (Denut, 2005, 16). The piece looks into the perceptive skills of human beings and the nature of sound when altered by "natural” tools such as a trumpet mute. "I have always been fascinated by the changes in character involved by the use of mutes on brass instruments, which enhances their expressive potential," Maresz said (Maresz, IRCAM - BRAHMS ${ }^{9}$ ) With this comment, the composer gives his piece anthropological, philosophical and aesthetic dimensions, and carries on with the 1970s quest aiming to improve sound perception to the point of recapturing tactile and bodily sensations akin to those traditional musicians feel with their instruments. As Anne Veitl writes, what musicians and researchers seek is "to enhance specifically human abilities, encourage and

\footnotetext{
${ }^{9}$ Data base of IRCAM, http://brahms.ircam.fr/
} 
improve them to give concrete expression to and perceive sounds, work on them, notably using various musical gestures.” (Veitl, 2004, 195). Hearing means listening, seeing and touching. The anthropological dimension can be appreciated from listeners' comments when they recognize sound fragments they have heard before amidst sounds heard for the first time.

The other feature of this music is to be partly electroacoustic and partly traditional. The instrument can be identified and the musical technique is typical, with or without a mute. The epistemological questioning requires explanations about the interplay between the electroacoustic and natural dimensions of the sound. Regarding the trumpet sound, it can be identified as such in numerous phases of the piece, and the use of mutes modifies it. These are "classical" procedures of alteration of the trumpet sound, which listeners have heard before, like the mute, wah-wah mute, cup mute, straight mute, Harmon or whisper mute. Conversely, the composer's endeavour to recreate the transformations operated by the different mutes in the trumpet sound will enable him to play with the difference between "the real sound picture and its spectral image” (Maresz, IRCAM - BRAHMS). To achieve this, he analyses the whole gamut of trumpet sounds with different mutes, using current software tools, then selects and reinserts them into the musical speech while the instrumentalist is playing. Maresz builds his piece starting from the natural sound of the trumpet and using "the mutes, from the slightest to the most salient sound effects possible, incorporating classical trumpet phrases (also shifting towards increasingly modified sound), during which the formant filtering is performed." (Maresz, Ibid). But he also uses traditional musical techniques such as the Flaterzunge, Doodle tonguing, Slap, Pops, etc.

For this work on sound, Maresz used the Max/MSP musical programming environment developed at IRCAM at the end of the 1980s, and applied to real time sound creation. This tool gives composers the opportunity to programme interactive sequences between musicians and computers. He also appealed to the sampling technique, which consists of sampling sounds that will subsequently be used by the musician; other types of sounds are triggered by direct-to-disk recording: samples recorded on the hard disk and triggered by the trumpet player. He also worked on spatialization, sound synthesizing with various filters, and sound processing, to generate harmonics during the live performance of the musical piece for example.

All the sounds edited through computer processing are reinserted into the temporal and aural progression of the musical piece. These sounds are also spatially organized at aural and geographical levels (Appendix 3).

The synthesizing of sounds appeals to acoustic and also perceptive skills. The structure of the musical piece takes the nature of the instrument into account and plays with it, thus providing Metallics with a specific intensity,

An emotional intensity (ranging from pure instrumental sound to interference sound), including surprising moments of formal interpretation, and constant sound quality through the creation of unprecedented aural spaces (contrasting wet and dry, full and empty textures in a matrix offering a wealth of meanings, which already existed in Jazz rock, and adding real and unreal sound rendering). The composer's achievement then lies in the poetics of sound, which takes us back to many sound memories covering a broad spectrum ranging from Baroque concertos by 
Maurice André to Bitches Brew, Miles Davis’ great album from the early 1970s. (Denut, 2005, 13-14)

The composer's musical piece is rooted in the historical tradition of the instrument. He re-uses musical techniques and intensity levels that belong to the trumpet's history and repertoire. He does not break with tradition but re-interprets it to bring change. The same goes for writing: indeed if the trumpet part is integrally written down, the "electronic part is only partially written (even symbolically sometimes). It will mainly serve as a marker for the interpreter" (cf. Metallics, p.2). The score is thus written down following three levels: the metronomic signal, the trumpet part and the electronic part (See III. 1).

\section{2. Metallics' function...}

The first function of this piece is the acoustic quest allowing the development of a spectral approach to the trumpet sounds, with or without a mute. It is a continuation of works as Partiels (1975) of Gérard Grisey or Désintégrations (1985) of Tristan Murail. Thanks to digital devices, this function also aims to use real time interactions between a musician and recorded sounds that were never heard before. Maresz's piece is based on traditional sound elements that the composer modifies until generating unheard-of sounds, in a constant coming and going between a daily sound reality and a constantly evolving one.

Another functional aspect of this musical piece is the live performance that puts the composer's aural and musical quests in contact with the audience. The concert both unveils the musical quest and provides entertainment, which is not necessarily the case with other types of electroacoustic, concrete and acousmatic music. It re-introduces the need for human presence in an electroacoustic sound space that could actually do without it. But as it fashions the sound dimension and spatialization, this function also reveals a demiurge musician who creates and organizes a new world, obviously one of the reasons for its success.

One last function - linked to music historicity and more particularly that of the chosen instrument - is virtuosity. This musical piece brings together several sound worlds, restores harmony between them and uses them to build its own structure. This virtuosity is not groundless and gives a meaning to the music by drawing on sound pictures listeners are familiar with. On the didactic level, the historical dimension of the musical piece provides meaning to this music, it appeals to deeper memories, to a re-identification of sound pictures buried in the subconscious memories of every listener (at least Westerners).

\section{From didactic analysis to the teaching of electroacoustic music: didactic transposition}

\section{1. A didactic analysis}

\section{1. 1. The teaching and learning environment}


What should we remember of research and how could we use it in the teaching process? The answer depends on the time allowed to teachers and students, on their skills and knowledge, on their interest in the study of such a musical piece, etc. Obviously, these issues recontextualize the course content (Brousseau, 1998, 41), objectives and methods within the limited time and space of a classroom. The teaching can be centred on several priorities whether they concern the relation between traditional musical notation and "basic information" for electroacoustic music, musical techniques, piece structure, work on mutes, computer-aided aural quest, etc.

Such a musical piece requires a stage of intersubjectivity so as to give everyone the opportunity to express their emotional feelings or technical viewpoints about the music they have just heard, depending on their personal abilities. The language used and the clues provided give basic indications on the perceptive abilities of listeners and on the avenues of research to be preferred for the course. Only hereafter can more technical concepts be examined. The structure of the course content is the teacher's and even the group's choice, and even though the priorities set for every objective are also the teacher's responsibility, listener's remarks should be taken into account to keep up their interest. Any didactic approach requires taking the specificities of the studied piece as well as the listener's perception into account. The piece must mean something to listeners, recall mental images, make representations resurface and spark a discussion. In an electroacoustic piece, and depending on students' prior knowledge, the interest lies in the way sounds are "manufactured". This interest is grounded in specific strategies, techniques and methods, and student/teacher dialogue is therefore of the essence to build up knowledge. The stage of intersubjectivity has always been privileged in education, either through the use of a Socratic maieutics, or through dialogue, as Saint Augustine puts it in his Confessions:

Where then (were these things entered into my memory)? Or wherefore, when they were spoken, did I acknowledge them, and said, "So is it, it is true," unless that they were already in the memory, but so thrown back and buried as it were in deeper recesses, that had not the suggestion of another drawn them forth I had perchance been unable to conceive of them? (Saint Augustine, $\mathrm{X}-\mathrm{X}, 213)$.

These discussions enable students to build up knowledge and reveal their ability to perceive and understand music. Didactic thought helps teachers prepare these sessions and lead them according to the group's expectations and abilities.

\section{1. 2. The learning objects}

Concerning techniques, as we already observed before, focus can be on the instrument and its mutes, considered as the starting point of the piece, and on computer-based tools necessary for the study and alteration of sounds. The identification of the different ways of emitting sounds, whether natural or electroacoustic, is probably the first task that requires total attention from listeners. In Metallics, the material is structured according to a hierarchy ranging from the most natural sound to the most altered one using mutes. The listening process may focus on the identification of the trumpet range of sounds, from natural sound - marked Open on the score - to sounds using mutes: Wah-Wah (stem in) when using the Wah-Wah mute with the tubing, 
or Harmon (stem out) using it without the tubing but with all the opening or closing possibilities of the latter, without forgetting the Whisper or Practice mute also called silent mute, and sounds processed using spectral image. However, playing techniques having an impact on the instrument sound also involve valves, slide, attacks such as flatterzungue ${ }^{10}$, Doodle tonguing ${ }^{11}$, glissandi performed with the slide, slaps ${ }^{12}$, Pops ${ }^{13}$, trills, staccato, etc. All are performance techniques that should be examined and analysed with students. The study is all the more so easily organised during the class as it has been prepared and planned through didactic thought.

Obviously, computer technology is largely used in this musical piece and a glossary available with the CD text gives listeners the opportunity to become acquainted with the different techniques. Whether in terms of the IRCAM software (Max/MSP) used in the creative process, sound synthesis with "harmonic" or "resonant" filters, spacialization effects or the processing operation resulting in real-time harmonisation, the whole gamut of sounds has been arranged, entered in the programmes and thus triggered by the instrumentalist by means of two tools offering enhanced interactivity between the instrument and the computer: a micro-sensor integrated in the mouthpiece which, thanks to a very accurate analysis of the entry signal, enables the monitoring of the pitches and amplitude of the notes, and a small trigger located on the instrument and operated by the musician's thumb. This technique offers the opportunity to activate sounds recorded on the computer hard disk, and is called direct-to-disk. (See electronic devices, the score and also Ircam documents). Regarding this point, the didactic thought analyses the interactions between man and instruments, as well as man and technology. This analysis occurs at two levels: that of the composer and the choices he/she makes when creating the musical piece, and that of the performer and the choices he/she makes when playing the piece. Such an analysis reveals the large range of performance modes available.

Software tools and techniques used are brought together by musical notation. Notation is the only connecting tool between the technological, musical and human worlds. It connects the three spheres and offers a link between the composer and the sound he/she wishes to obtain, the computer operated by technicians and the sound it generates, and the performer. The score (See III. 1) is divided into staves, each of them having three levels. The first level is designed for the "Click" sent to the trumpet player as a time marker. It gives the beat and variations in meters and tempo - the first tempo always having the stem pointing up - and never stops. The second level represents the trumpet player's staff and is written in traditional notation with indications of duration, timbre, intensity, pitches and performance techniques as well as clues for the insertion of mutes at the different stages of the piece. The third level is a symbolic representation of the electronic score. "Nota: the electronic score has very few notations (sometimes only symbolic). It is mainly used as a marker for the performer (Durand, 2).”

\footnotetext{
${ }^{10}$ Fluttering motion of the tongue is a technique used with transverse flute.

${ }^{11}$ Articulation mode based on the alternation of "d" and "l" with a movement of the tongue that reduces the airflow and results in giving a voice-like articulation to the notes produced.

${ }^{12}$ To play slapping one's tongue

${ }^{13}$ Idem.
} 


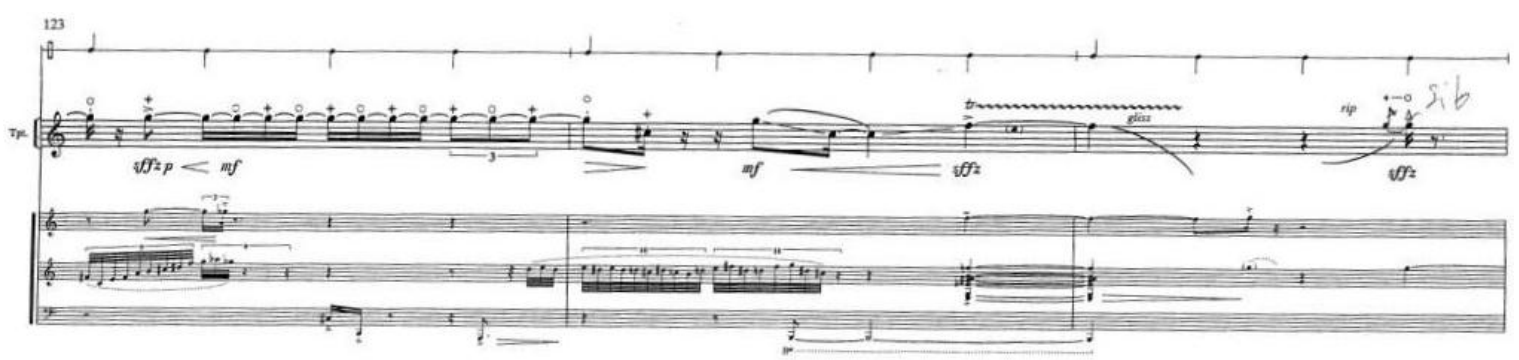

III. 1: extract from Metallics score, for solo trumpet and live electronics, Éditions Durand, p. 8.

This graphic representation gives clues to the composer's musical intentions and reference points for identifying natural acoustic and electroacoustic passages. It is a tool for establishing relations - however imperfectly - between the two sound spaces. Moreover, exploring the writing methods of an electroacoustic piece on the epistemological level is of significant interest. What determined the way musical elements were notated? Didactic questioning on playing modes, sound rendering and transmission of musical thought highlight the composer's motivations and choices.

We could assume that the aesthetic, philosophical and scientific dimensions belong to external didactic transposition. In the internal didactic transposition process, the composer's educational path and that of the musicians he has met or played with, the musical cultures and styles he studied, cannot be overlooked. The aesthetical aspect of this musical piece depends on the musician's life history, his relation to music and more generally with the world around him. This anthropological analysis of the learning object is necessary for understanding the piece. Metallics not only reveals this life history, the influence of jazz, jazz-rock, jazz-fusion, but also a mastery of classical writing combined with questions about the nature of sound, which are quite common among composers of electroacoustic music. This is the work of a craftsman, the result of a technique, and of the composer's personal search in his relationship with music. The artist's testimonies, both verbal and written, are clues in the same way as the sound object or score. They provide information on the musical piece.

\section{2. Discussion}

Listening to the musical piece and observing the musical notations and graphs left by the composer as so many traces to be followed both give the teacher the opportunity to comprehend the piece. These traces are the many clues that the teacher may rely on to help students become acquainted with this musical world where sounds never heard before prevail.

Didactics brings the teacher to place the musical piece in a context that is not the original one. Created for concert purposes, it has become a learning object designed for building up knowledge, and requiring that the various founding elements be distinguished, reorganised and divided into as many aspects as can be studied. The teaching method compels the teacher to make choices, organise them within the timeframe of the class, and ignore some of them in favour of others. While the didactic study of a piece fosters better knowledge of it and better 
understanding of its ins and outs, it also sets limits to the teaching function. These limits are set by the complexity of the piece as a learning object, by the time dedicated to it, by the people with whom we are going to explore it, and also by the "ideological" choices made by the teacher. If the scientific and social hindrances play a significant part in the teaching of an electroacoustic piece, they do not prevent the teacher from trying to understand its material better.

What didactic analysis of the piece reveals, is just as well aimed at student-composers of electroacoustic music, as performers or listeners. The teacher adjusts his/her requirements to the students with whom he/she collaborates. This type of analysis is of interest for composers who, considering their works as learning objects, become aware of the elements involved in the creative process of their musical compositions, sometimes without their knowledge. As confirmed in this paper, didactics, and more particularly didactic transposition, obviously sheds a new light on the musical piece. The research and analysis carried out disclose the various elements that have come into its creation, organize these elements so as to make them operational in an educational context, and give students and listeners the opportunity to understand the music through listening sessions and exchanges adapted to everyone.

\section{Conclusion}

Our initial assumption was based on the fact that a thoughtful didactic analysis enables teachers specialized in electroacoustic music to better understand the nature and functions of this type of music, and to adjust their teaching methods to the target audience. The didactic tools described in the first part of this paper contribute to elaborate a methodology and to define the musical piece in terms of its "structural economy", that is its internal organization. The epistemological questioning on the analysis of Metallics identifies the main founding elements of this piece. Didactic thought leaves the teacher free to choose the structure of his/her course and adapt the educational strategies to the level of his students. Does that mean that didactics and electroacoustic composition are the same? Of course not! Considering a musical piece as a learning object does not mean composing it. It is a matter of trying to understand how a certain number of its elements are organized and where they originate from. Didactic thought always follows the act of creation, it is a means to bring to light elements that contributed to its production, and sometimes to go back to its genesis. Didactics does not explain the creative process, it helps understand a posteriori the progression and tools used for the production of the object.

Translated by Pierre Bouillon, Université catholique de l'ouest, L'UNAM. 


\section{BIBLIOGRAPHY}

BARBANTI, R. 2004. "Aux origines des arts multimédias : le rôle des instruments de 'reproduction' acoustique". In BARBANTI. R. LYNCH. E. PARDO. C. SOLOMOS. M. (sous la direction de). Musique, arts, technologies, pour une approche critique. Paris: L'Harmattan. 2134.

BATTIER. M. 2003. "Laboratoires". In NATTIEZ. J.-J. (sous la direction de). Musiques, une encyclopédie pour le XXIe siècle, Musique du XXe siècle. Vol. I. Paris: Actes Sud/Cité de la musique. 558-573.

BROUSSEAU. G. 1998. Théorie des situations didactiques. Grenoble: La Pensée Sauvage éditions.

CHEVALLARD. Y. 1999. L'analyse des pratiques enseignantes en théorie anthropologique du didactique. Recherches en Didactique des Mathématiques 19(2): 221-266.

CHEVALLARD. Y. 1985. La transposition didactique. Grenoble: La pensée sauvage.

CRITON. P. 2004. Tékhnè et expressivité. ". In BARBANTI. R. LYNCH. E. PARDO. C. SOLOMOS. M. (sous la direction de). Musique, arts, technologies, pour une approche critique. Paris: L’Harmattan. 245-253.

DELALANDE. F. 2003. Le paradigme électroacoustique. In NATTIEZ. J.-J. (sous la direction de). Musiques, une encyclopédie pour le XXIe siècle, Musique du XXe siècle. Vol. I. Paris: Actes Sud/Cité de la musique. 533-557.

DENUT. É. 2005. Le sens retrouvé, à propos de la musique de Yan Maresz. Booklet CD IRCAM Compositeurs d'aujourd'hui. Universal/accords 476720.

DEVELAY. M. (sous la direction de) 1997. Le sens d'une réflexion épistémologique. Savoirs scolaires et didactiques : une encyclopédie pour aujourd'hui. Paris: E.S.F. 17-31.

DEVELAY. M. 1991. La face cachée des disciplines scolaires. Cahiers pédagogiques 298 nov. 25-27.

JOHSUA. S. DUPIN J.-J. 1993. Introduction à la didactique des sciences et des mathématiques. Paris: PUF.

MARESZ. Y. Metallics. Notes de programme. IRCAM - Brahms - Base de documentation sur la musique contemporaine. http://brahms.ircam.fr/works/work/10522/\#program.

MARESZ. Y. Metallics. http://www.yanmaresz.com/catalogue/metallics

MARESZ. Y. Metallics. http://www.youtube.com/watch?v=2lHhpBLk_eU

Mc ADAMS. S. BIGAND. E. 1994. Penser les sons, psychologie cognitive de l'audition. Paris: PUF.

POPPER. F. 1993. L'art à l'âge électronique. Paris: Hazan.

ROUSSEAU. J.-J. 1966. Émile ou de l'éducation, Livre Troisième. Paris: Garnier Flammarion. ROY. S. 2003. L'analyse des musiques : modèles et propositions. Paris: L’Harmattan.

SAINT AUGUSTIN. 1964. Les Confessions. Livre X (X). Paris: Garnier-Flammarion.

TERRIEN. P. 2006. L'écoute musicale au collège, fondements anthropologiques et psychologiques. Paris: L'Harmattan.

TERRIEN. P. 2012. Musique et Vidéo. Contribution à la réflexion et à l'action pédagogique (I). Paris: L’Harmattan.

VEITL. A. 2004. Le compositeur à l'ordinateur (1955-1985) : des moyens de rationalisation aux outils de réellisation. In BARBANTI. R. LYNCH. E. PARDO. C. SOLOMOS. M. (sous la 
direction de). Musique, arts, technologies, pour une approche critique. Paris: L'Harmattan.185201.

VERRET. M. 1975. Le temps des études. Paris: Librairie Honoré Champion.

\section{Score}

Metallics, pour trompette solo et dispositif électronique, Éditions Durand, 1995.

CD

MARESZ. Y. 2004, Metallics. IRCAM Compositeurs d'aujourd'hui. Universal/accords 476 720. 


\section{APPENDIX 1}

\section{Didactic transposition}

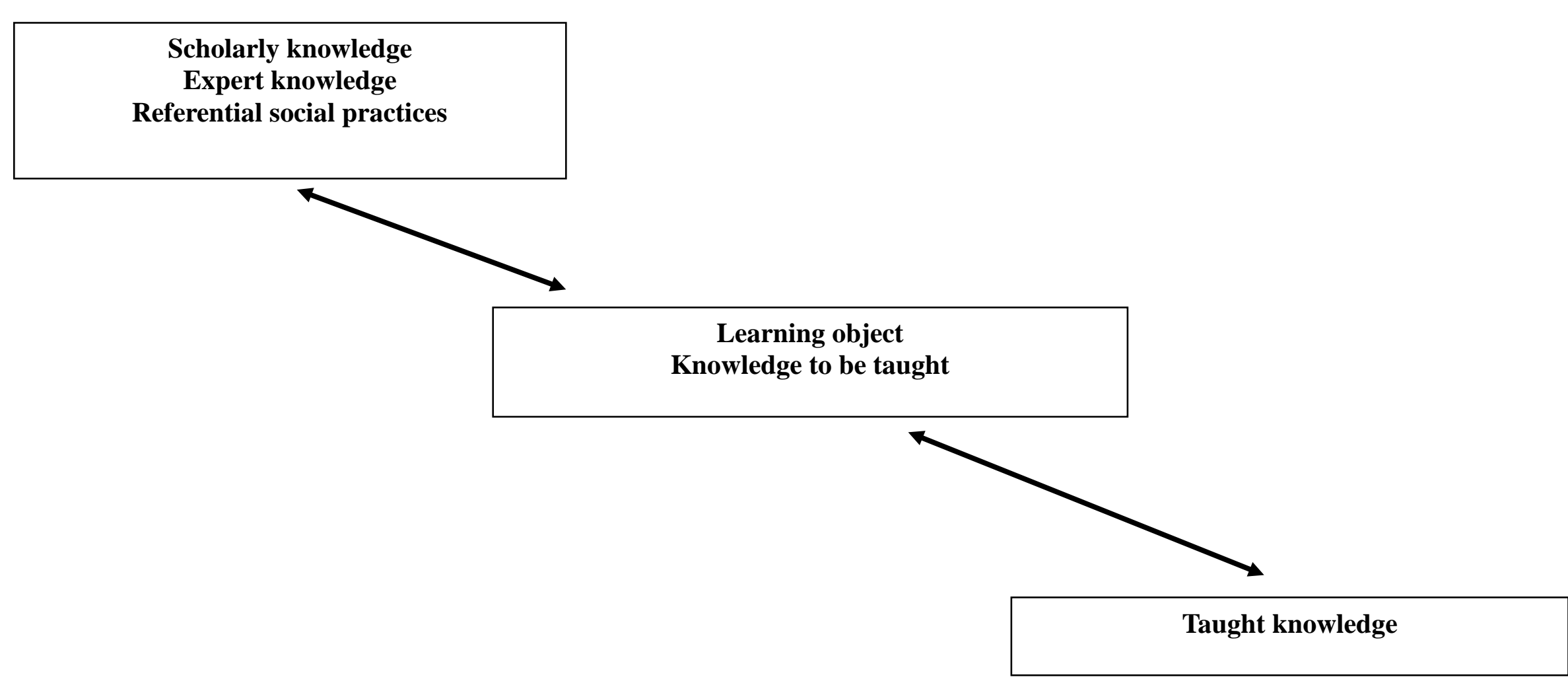

Didactic situation

And non- didactic situation,

didactic devolution 


\section{APPENDIX 2}

\section{Didactic triangle}

Knowledge

(submitted to didactic transposition)

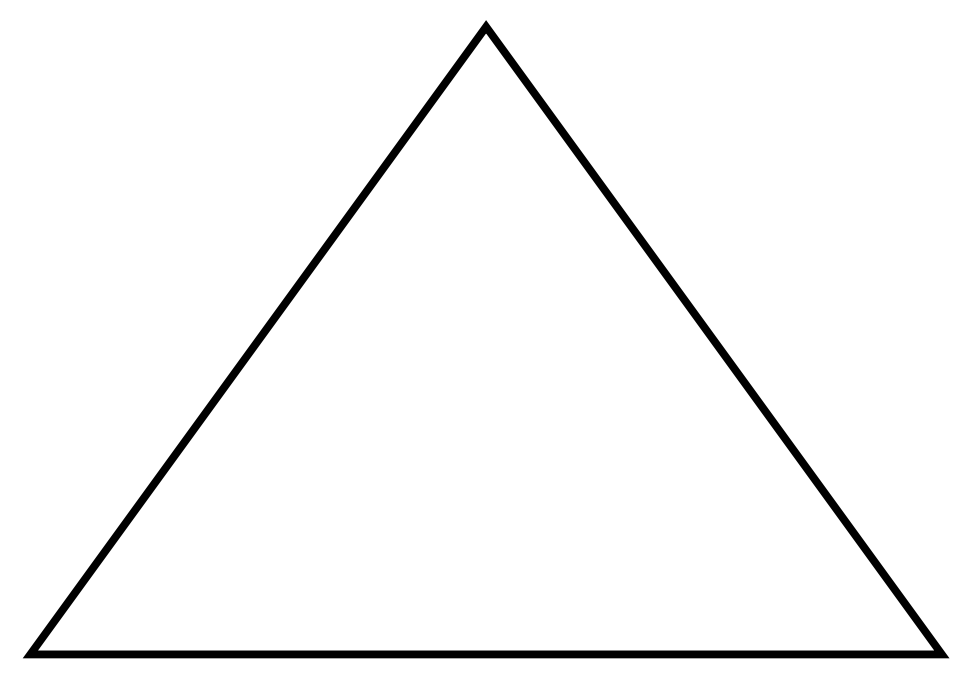

The teacher

(with his/her personal idelology)

The student

(with his/her personal cognitive structure)

JOHSUA Samuel, DUPIN Jean-Jacques, Introduction à la didactique des sciences et des mathématiques, Paris, PUF, 1993 


\section{APPENDIX 3}

\section{Configuration de la version avec bande ( 4 pistes)}

Aux Editions DURAND

Bande 4 pistes: 3 Formats disponibles

- ADAT
- Hi 8

PRO TOOLS (Fichiers sur CD-Rom)

Pour le Trompettiste

- Partition

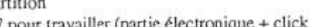

I. dicnnsitif

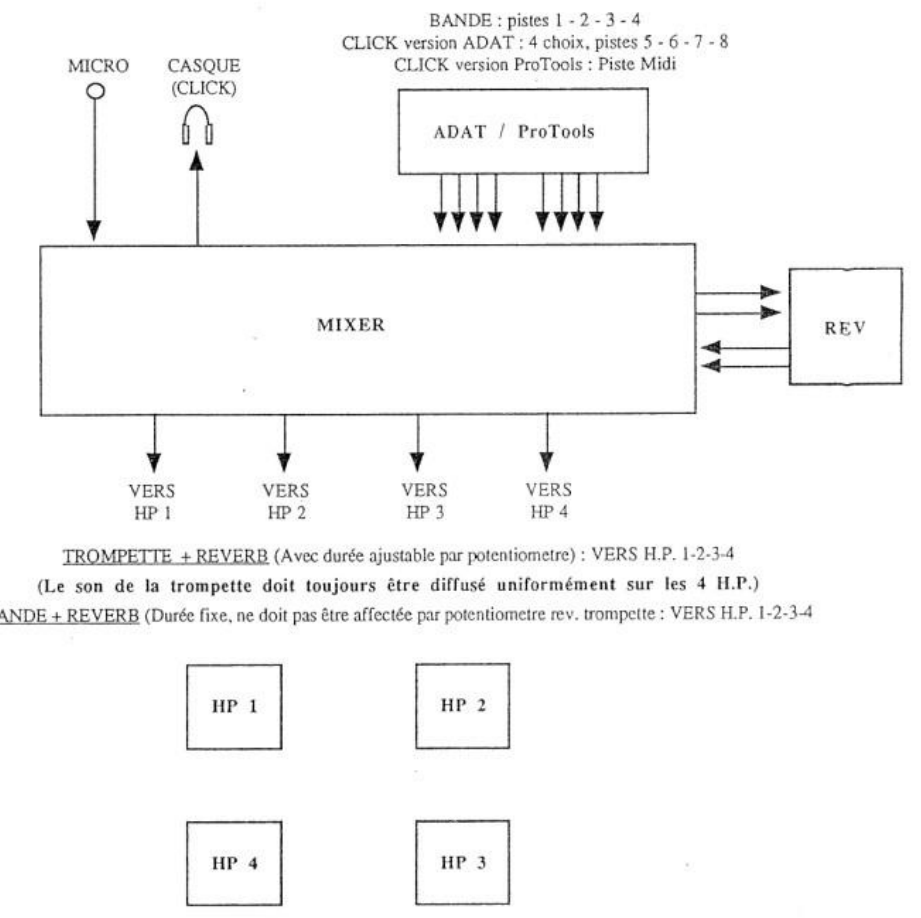

$C f$. Description of Durand Publisher

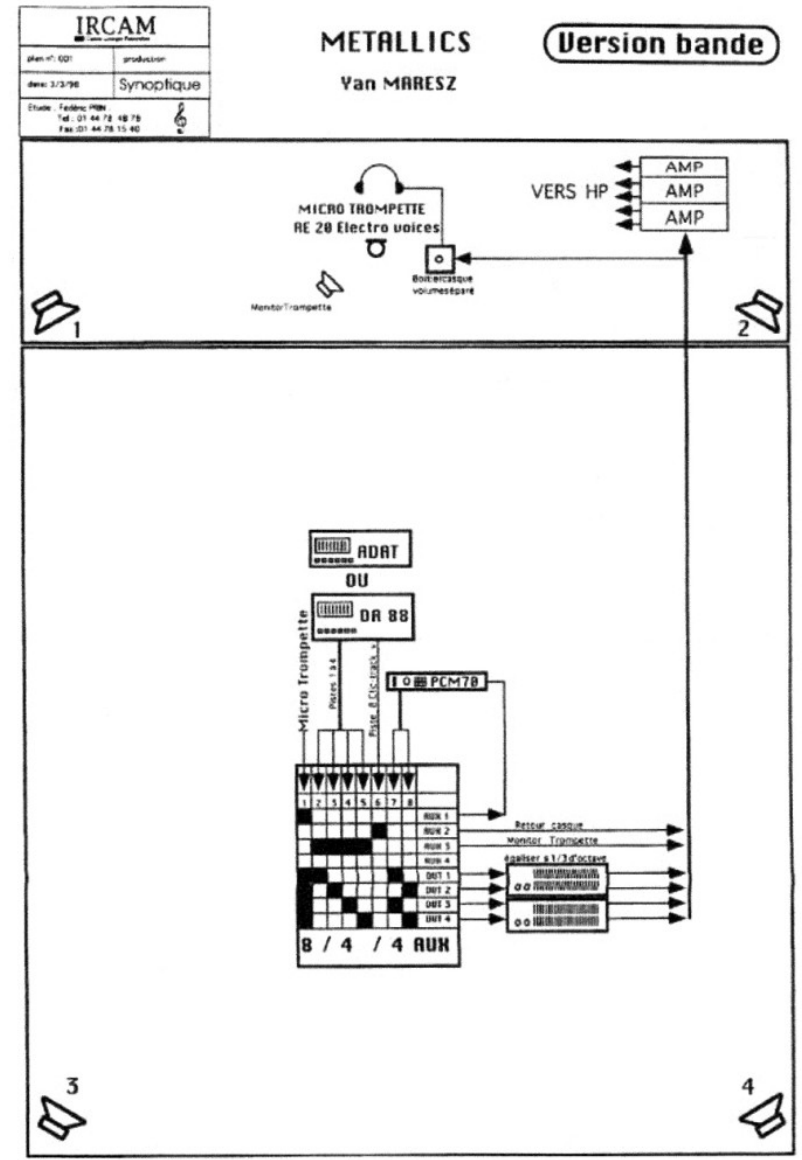

Document IRCAM 